\title{
PENGARUH MODEL PEMBELAJARAN COOPERATIVE LEARNING TIPE GROUP INVESTIGATION TERHADAP HASIL BELAJAR MATEMATIKA SISWA KELAS V SD
}

\author{
Ni Made Santi Widyasari ${ }^{1, *}$, Safruddin ${ }^{2)} \&$ Awal Nur Kholifatur Rosyidah ${ }^{3)}$ \\ 1), 2), 3) Universitas Mataram, Mataram, Indonesia \\ E-mail: santiwidia@gmail.com
}

\begin{tabular}{|c|c|}
\hline INFORMASI ARTIKEL & ABSTRAK \\
\hline $\begin{array}{l}\text { Article history } \\
\text { Received: August 18, } 2020 \\
\text { Revised: September 9, } 2020 \\
\text { Accepted: September 10, } 2020 \\
\text { Kata kunci: } \\
\text { model pembelajaran, } \\
\text { cooperative learning, tipe } \\
\text { group investigation, hasil } \\
\text { belajar matematika }\end{array}$ & $\begin{array}{l}\text { Penelitian ini bertujuan untuk mengetahui pengaruh model pembelajaran } \\
\text { cooperative learning tipe group investigation terhadap hasil belajar } \\
\text { matematika pada aspek kognitif siswa kelas } V \text { SDN } 26 \text { Ampenan. Jenis } \\
\text { penelitian yang digunakan adalah penelitian eksperimen dengan desain } \\
\text { penelitian Quasi Eksperimental tipe Nonequivalent Control Group Design. } \\
\text { Populasi pada penelitian ini ialah seluruh siswa kelas V di SDN } 26 \text { Ampenan. } \\
\text { Sampel penelitian diambil menggunakan teknik sampel jenuh, dimana semua } \\
\text { jumlah populasi dijadikan sampel. Metode pengumpulan data yang } \\
\text { digunakan pada penelitian ini adalah tes, observasi, dan dokumentasi. Uji } \\
\text { hipotesis pada penelitian ini menggunakan rumus independent samples t-test. } \\
\text { Hasil analisis data menggunakan program SPSS Versil6.0 menunjukkan } \\
\text { nilai thitung adalah } 6,561 \text { dan tabel } 1,675 \text { dimana nilai thitung } \geq \text { tabel atau dengan } \\
\text { melihat nilai Sig. }(2-t a i l e d) 0,000 \leq 0,05 \text { pada taraf signifikansi } 5 \% \text { dengan df } \\
51 \text { maka } H_{a} \text { diterima yang berarti terdapat pengaruh model pembelajaran } \\
\text { cooperative learning tipe group investigation terhadap hasil belajar } \\
\text { matematika pada aspek kognitif siswa kelas V SDN } 26 \text { Ampenan tahun ajaran } \\
2019 / 2020 \text {. Hal ini dibuktikan dari sintaks kegiatan pembelajaran bahwa } \\
\text { penggunaan model pembelajaran cooperative learning tipe group } \\
\text { investigation pada pertemuan pertama dan kedua terlaksana dengan kategori } \\
\text { sangat baik. }\end{array}$ \\
\hline
\end{tabular}

\section{A. PENDAHULUAN}

Pendidikan merupakan suatu hal yang penting bagi manusia, dengan pendidikan manusia dapat memperoleh ilmu pengetahuan. Untuk menunjang pencapaian tujuan pendidikan di Sekolah Dasar, perlu dibantu oleh model pembelajaran yang tepat dan sesuai dengan karakteristik siswa. Harapannya agar mampu meningkatkan keaktifan dan partisipasi yang tinggi dalam belajar. Pada dunia pendidikan terdapat istilah yang menunjukkan pencapaian siswa dalam memahami pembelajaran. Istilah tersebut dikenal dengan hasil belajar. Hasil belajar merupakan perubahan-perubahan yang terjadi pada diri siswa, baik yang menyangkut kognitif, afektif, dan psikomotor sebagai hasil dari kegiatan belajar (Dimyati, 2013:7). Menurut Sudjana (2017:22) hasil belajar adalah kemampuan-kemampuan yang dimiliki siswa setelah ia menerima pengalaman belajar. Sedangkan menurut Winkel (dalam Purwanto, 2016:45) hasil belajar adalah perubahan yang mengakibatkan manusia berubah dalam sikap dan tingkah 
lakunya. Tentu hal ini berlaku setelah siswa belajar semua mata pelajaran di sekolah, tanpa terkecuali pelajaran matematika.

Mata pelajaran matematika perlu diberikan di semua jenjang pendidikan, termasuk salah satunya adalah Sekolah Dasar (SD). Siswa yang belajar matematika akan berlatih bernalar kritis, kreatif, dan aktif (Maulyda et al., 2019; Maulyda et al., 2020; Annizar et al., 2020). Matematika merupakan ide-ide abstrak yang berisi simbol-simbol, maka konsep matematika harus dirangkai terlebih dahulu sebelum memanipulasi simbol-simbol tersebut. Pembelajaran matematika hendaknya mengajak siswa untuk ikut serta dalam proses memahami suatu materi dengan turut memberikan argumentasi dan berkontribusi dalam penyelesaian masalah. Untuk menjembatinya, guru perlu memikirkan cara penyampaian materi secara efektif agar mudah diterima oleh siswa secara nyata (realistis) yaitu dengan memaksimalkan penggunaan model yang sesuai dalam pembelajaran.

Berdasarkan hasil observasi yang telah dilaksanakan masih banyak ditemui masalahmasalah dan kesulitan dalam proses pembelajaran khususnya matematika di SDN 26 Ampenan, dikarenakan guru jarang mengimplementasikan model pembelajaran inovatif saat penyampaian materi. Metode yang digunakan guru kurang bervariasi dan kreatif, guru hanya menggunakan metode ceramah. Guru meminta siswa membaca bukunya untuk memahami materi, tanpa dibarengi dengan penjelasan secara maksimal kepada siswa. Hal tersebut membuat siswa semakin kurang mengerti atas materi yang disampaikan, yang berakibat hasil belajar matematika rendah. Rata-rata hasil belajar matematika siswa terbilang rendah yaitu dibawah kriteria ketuntasan minimal (KKM) yang telah ditentukan sekolah yaitu 7,0 jika dibandingkan dengan mata pelajaran lainnya. Melalui pembelajaran yang kreatif, inovatif, dan menyenangkan serta melibatkan siswa secara langsung dalam proses pembelajaran dapat membantu siswa mencapai hasil belajar matematika yang maksimal.

Untuk mengatasi hal tersebut, salah satu cara yang dapat dilakukan adalah dengan memperbaiki model pembelajaran, yang menuntut siswa untuk terlibat secara aktif dan memiliki partisipasi yang tinggi dalam kegiatan pembelajaran. Setting pembelajaran yang sifatnya individual ketika menyelesaikan Lembar Kerja dimodifikasi menjadi setting pembelajaran kelompok atau kooperatif. Rangkaian kegiatan belajar yang dilakukan oleh siswa dalam kelompok-kelompok kecil dapat membantu untuk mencapai tujuan pem-belajaran yang dirumuskan (Putri, Dewi \& Rosyidah, 2020: 227). Sehingga diharapkan dapat mencapai hasil belajar yang maksimal pada aspek kognitif siswa. Salah satu caranya adalah penggunaan model 
pembelajaran cooperative learning tipe group investigation yang secara umum dirancang untuk membimbing para siswa untuk menyelidiki dalam proses menyelesaikan suatu masalah.

Model pembelajaran Cooperative Learning Tipe Group Investigation (GI) dapat digunakan guru untuk mengembangkan kreativitas dan keaktifan baik secara individu maupun secara kelompok. Menurut Rusman (2012:222) bahwa model pembelajaran Cooperative Learning tipe Group Investigation dirancang untuk membantu terjadinya pembagian tanggung jawab ketika siswa mengikuti pembelajaran dan berorientasi menuju pembentukan manusia sosial. Model pembelajaran Cooperative Learning tipe Group Investigation ini akan membuat siswa lebih aktif dan antusias dalam mengikuti pembelajaran matematika, sehingga siswa akan memperoleh hasil belajar yang maksimal pada aspek kognitif.

Menurut Indrawati (2018:2) dari hasil penelitiannya meyebutkan bahwa ada pengaruh model pembelajaran kooperatif tipe Group Investigation (GI) terhadap hasil belajar matematika siswa. Dibuktikan dari hasil perhitungan bahwa rata-rata hasil belajar siswa pada kelas eksperimen lebih tinggi dibandingkan dengan rata-rata hasil belajar siswa pada kelas kontrol. Penerapan model cooperative learning tipe group investigation pada proses pembelajaran mampu menunjukkan siswa aktif berinteraksi dalam kelompok untuk membentuk suatu konsep belajar. Dalam artian hasil belajar matematika siswa dengan model pembelajaran GI lebih baik dari pada hasil belajar matematika siswa dengan pembelajaran konvensional. Keterkaitan antara penelitian di atas dengan penelitian ini yaitu sama-sama menggunakan model cooperative learning tipe group investigation sebagai variabel bebas dan hasil belajar sebagai variabel terikat. Sedangkan perbedaannya terletak pada karakteristik siswa, materi yang digunakan pada saat penelitian, serta hasil perhitungan nilai rata-rata pretes dan posttes kelas eksperimen dan kelas kontrol. Dari berbagai masalah yang telah dipaparkan di atas, maka tujuan penelitian ini adalah mendeskripsikan pengaruh model cooperative learning tipe group investigation terhadap hasil belajar matematika pada aspek kognitif siswa kelas V SDN 26 Ampenan tahun ajaran 2019/2020.

\section{B. METODE PENELITIAN}

Jenis penelitian ini adalah kuasi eksperimen. Menurut Sugiyono (2017:72) penelitian eksperimen dapat diartikan sebagai metode penelitian yang digunakan untuk mencari pengaruh perlakuan tertentu terhadap yang lain dalam kondisi yang terkendali. Setara dengan itu, Arikunto (2014:19) mengatakan bahwa penelitian eksperimen adalah suatu cara untuk mencari hubungan sebab akibat (hubungan kausal) antara dua faktor yang sengaja ditimbulkan oleh 
peneliti dengan mengeliminisasi atau mengurangi atau menyisihkan faktor-faktor lain yang mengganggu.

Variabel bebas (independen) penelitian ini adalah model pembelajaran cooperative learning tipe group investigation, sedangkan variabel terikat (dependen) penelitian ini adalah hasil belajar matematika. Penelitian dilakukan di kelas V di SDN 26 Ampenan pada semester genap tahun ajaran 2019/2020. Subyek penelitian ini adalah seluruh siswa kelas V SDN 26 Ampenan. Jumlah populasi penelitian ini adalah 53 siswa dengan besar sampel juga sejumlah 53 siswa. Pengambilan sampel menggunakan teknik sampling jenuh, karena semua anggota populasi dijadikan sampel. Teknik pengumpulan data pada penelitian ini berupa tes, observasi, dan dokumentasi. Instrumen yang digunakan dalam penelitian berupa lembar tes dan lembar observasi hasil belajar matematika siswa. Jumlah item dalam soal tes sebanyak 8 soal, yang terdiri dari 5 soal pilihan ganda dan 3 soal uraian. Data penelitian dianalisis dengan teknik korelasi Product Moment (r) dibantu dengan SPSS Versi 16.0.

\section{HASIL DAN PEMBAHASAN}

Hasil uji statistik terhadap hasil belajar siswa kelas V (lima) SD Negeri 26 Ampenan disajikan pada Tabel 1 .

Tabel 1. Hasil Uji Statistik Pada Hasil Belajar Kognitif

\begin{tabular}{|c|c|c|c|c|c|c|c|}
\hline No & $\begin{array}{l}\text { Uji Analisis } \\
\text { Data }\end{array}$ & \multicolumn{2}{|c|}{ Kelas } & $\begin{array}{c}\text { Jumlah } \\
\text { Siswa }\end{array}$ & Lhitung & $\mathbf{L}_{\text {tabel }}$ & Kesimpulan \\
\hline \multirow{4}{*}{1.} & \multirow{4}{*}{ Uji Normalitas } & Eksperimen & Pretes & \multirow{2}{*}{24} & 0,225 & \multirow{2}{*}{0,05} & \multirow[t]{2}{*}{ Normal } \\
\hline & & & Posttest & & 0,136 & & \\
\hline & & \multirow[t]{2}{*}{ Kontrol } & Pretes & \multirow{2}{*}{29} & 0,173 & C 05 & \multirow[t]{2}{*}{ Normal } \\
\hline & & & Posttest & & 0,088 & 0,05 & \\
\hline \multirow{4}{*}{2.} & \multirow{4}{*}{$\begin{array}{l}\text { Uji } \\
\text { Homogenitas }\end{array}$} & & & \multirow{4}{*}{51} & $F_{\text {hitung }}$ & $\mathrm{F}_{\text {tabel }}$ & \multirow{4}{*}{ Homogen } \\
\hline & & Eksperimen & & & 0740 & 403 & \\
\hline & & kontrol & & & & & \\
\hline & & & & & $\mathrm{T}_{\text {hitung }}$ & $\mathrm{T}_{\text {tabel }}$ & \\
\hline 3. & Uji Hipotesis & $\begin{array}{l}\text { Eksperimen } \\
\text { terhadap } \\
\text { kontrol }\end{array}$ & & 51 & 6,561 & 1,675 & $\mathrm{H}_{\mathrm{a}}$ diterima \\
\hline
\end{tabular}

Berdasarkan tabel diatas, dijelaskan bahwa hasil uji normalitas pada hasil belajar matematika dinyatakan berdistribusi normal dibuktikan dari nilai signifikansi dari pre-test dan post-test kedua kelas menghasilkan nilai Sig. > dari 0,05. Hasil uji homogenitas dinyatakan homogen, dibuktikan dari hasil perhitungan data nilai pre-test dan post-test kedua kelas yang menghasilkan nilai $F_{\text {hitung }}$ lebih kecil dari nilaiF $F_{\text {tabel, }}$ yaitu $(0,740 \leq 4,03)$. Sedangkan hasil uji 
hipotesis mendapatkan hasil bahwa nilai $t_{\text {hitung }} \geq$ nilai $t_{\text {tabel }}$ atau dengan melihat nilai Sig. (2tailed) $0,000 \leq 0,05$ dengan df 51 maka $\mathrm{H}_{\mathrm{a}}$ diterima dan $\mathrm{H}_{0}$ ditolak.

Dari penjabaran di atas, dapat disimpulkan bahwa ada pengaruh model pembelajaran cooperative learning tipe group investigation terhadap hasil belajar matematikaaspek kognitif pada siswa kelas V SDN 26 Ampenan tahun ajaran 2019/2020. Hal tersebut dibuktikan dari proses pembelajaran selama penelitian berlangsung. Group investigation ini merupakan model pembelajaran berkelompok, yang memiliki enam sintaks atau enam langkah-langkah pembelajaran yaitu grouping, planning, investigation, organizing, presenting, dan evaluation.

Pada langkah pertama (grouping), yaitu siswa dibagi kedalam bentuk kelompok. Langkah kedua (planning), siswa dan guru menyiapkan bahan, media dan alat pembelajaran seperti guru membagikan kubus kepada setiap kelompok, dan siswa menyiapkan bahan-bahan seperti karton manila, gunting, pensil, penggaris dan penghapus. Peneliti menggunakan media berupa kubus bongkar pasang dan masing-masing kelompok diberikan satu buah kubus dengan ukuran panjang sisi yang berbeda. Selanjutnya guru memberikan LKPD kepada setiap kelompok untuk memudahkan penyelesaian masalah, lengkap dengan langkah-langkah pengerjaannya.

Langkah ketiga (investigation), siswa memulai dengan membongkar kubus tersebut menjadi jaring-jaring kubus lalu mencari panjang sisi kubus dengan cara mengukur menggunakan penggaris, setelah itu menghitung volume kubus dengan panjang sisi yang telah diukur sebelumnya. Berdasarkan uraian dari langkah pertama sampai ketiga di atas menekankan bahwa pembelajaran kooperatif tipe GI merupakan salah satu model pembelajaran kooperatif yang berfokus pada partisipasi dan aktivitas siswa untuk mencari sendiri materi (informasi) pelajaran yang akan dipelajari melalui bahan-bahan yang tersedia (Linuhung \& Sudarman, 2016: 58). Dibuktikan dengan keterlibatan siswa sejak perencanaan, kegiatan membongkar kubus menjadi jaring-jaring kubus, sampai pada kegiatan penyelesaian Lembar Kerja (LK) tentang menghitung ukuran panjang sisi dan volume kubus.

Langkah keempat (organizing), setelah mengetahui hasilnya setiap kelompok membuat kesimpulan dan laporan akhir. Langkah kelima (presenting), setiap kelompok mempresentasikan hasil diskusinya di depan kelas. Siswa sangat bersemangat saat melakukan presentasi serta kelompok lain sangat antusias dalam menanggapi dan memberi pertanyaan. Penjelasan di atas diperkuat dengan pendapat dari Ulia (2016: 57) yang mengatakan bahwa model pembelajaran Group investigation dapat meningkatkan aktivitas siswa untuk menyampaikan ide-ide, dikarenakan adanya keterlibatan siswa secara langsung mulai dari perencanaan dan melakukan berbagai investigasi untuk memahami materi. Sedangkan pada 
langkah keenam yaitu evaluation, guru dan siswa melakukan evaluasi terkait pembelajaran yang telah dilaksanakan.

Sedangkan kegiatan pembelajaran di kelas kontrol menggunakan model pembelajaran konvensional. Proses pembelajaran pada kelas kontrol yaitu guru membuka pelajaran dan menyuruh siswa untuk membaca buku terkait materi pelajaran volume bangun ruang kubus. Guru menjelaskan materi pelajaran menggunakan media satu buah kubus. Selanjutnya guru membagi siswa ke dalam beberapa kelompok dan membagikan LKPD kepada setiap kelompok. Tiap-tiap kelompok diwakili oleh satu orang siswa untuk maju ke depan mengukur kubus secara bergiliran. Siswa terlihat kurang bersemangat dalam mengikuti pembelajaran dan cenderung tidak fokus ketika memperhatikan penjelasan guru. Ini terjadi tidak hanya karena perbedaan media yang digunakan pada kedua kelas, melainkan karena perbedaan sintaks atau langkah-langkah model pembelajaran dan proses pembelajaran yang berlangsung diantara kedua kelas.

Pada penelitian ini media hanya digunakan sebagai alat bantu saat guru menerangkan materi pelajaran yang disampaikan, agar siswa lebih mudah berfikir secara kongkrit di dalam menyelesaikan sebuah permasalahan yang disajikan. Penelitian ini berfokus pada pengaruh model pembelajaran cooperative learning tipe group investigation terhadap hasil belajar matematika siswa pada ranah kognitif.Hal inilah yang menyebabkan hasil nilai posttest pada kelas eksperimen lebih tinggi dibandingkan dengan kelas kontrol.Perbedaan hasil belajar siswa terjadi karena model pembelajaran cooperative learning Tipe group investigation menjadikan siswa lebih antusias bekerjasama dalam tugas kelompok dibandingkan dengan model pembelajaran konvensional.

Beberapa hasil penelitian yang mendukung penjelasan diatas yaitu penelitian yang dilakukan oleh Nurlaeli dan Sri Yulianti (2014) menjelaskan bahwa penerapan model pembelajaran kooperatif tipe Group Investigation (GI) berbasis lesson study dapat meningkatkan hasil belajar kognitif pada siswa kelas VIII di SMP Negeri 1 Gunungsari. Hal tersebut dapat dilihat dari persentase hasil belajar kognitif siswa sebesar 58,8\% meningkat menjadi $88,2 \%$. Hasil belajar matematika siswa yang menggunakan model GI lebih baik dibandingkan dengan kelas yang menggunakan pembelajaran konvensional. Menurut Irma Ayuwanti (2016) dalam penelitiannya menjelaskan bahwa pembelajaran dengan cooperative learning tipe group investigation dapat meningkatkan hasil belajar matematika siswa kelas $\mathrm{X}$ SMK Tuma'ninah Yasin Metro semester genap tahun ajaran 2015/2016. Hal ini dapat dilihat dari rata-rata hasil belajar siswa yang meningkat dari $27,5 \%$ pada siklus I menjadi $54,54 \%$ pada 
siklus II, dan dari 54,54\% pada siklus II menjadi 81,81\% pada siklus III. Bagi guru bidang studi matematika kiranya dapat menerapkan model pembelajaran kooperatif model tipe Group Investigation (GI) dalam pembelajaran sebagai salah cara untuk meningkatkan aktivitas dan hasil belajar siswa.

Menurut penelitian yang dilakukan oleh Herman Alimuddin (2017), berdasarkan analisis statistik deskriptif maka diperoleh hasil belajar matematika siswa kelas VII Genetika menggunakan model pembelajaran kooperatif tipe Group Investigation diperoleh skor rata-rata sebesar 73,67 dan standar deviasi 8.479 berada antara interval 80-100. Serta pada hasil belajar matematika siswa kelas VII Gajahmada, model pembelajaran konvensional terlihat bahwa ratarata skor hasil belajar siswa sebesar 69,92 dan standar deviasi 76,25 berada diantara interval 44.4. Perbedaan skor hasil belajar siswa terjadi karena model pembelajaran kooperatif tipe Group Investigation menjadikan siswa lebih antusias bekerja dalam tugas kelompok. Hal ini ditunjukkan oleh banyaknya siswa yang aktif dalam mengajukan pertanyaan, maupun menanggapi pertanyaan yang berkaitan dengan materi ajar.

\section{SIMPULAN}

Bedasarkan hasil penelitian, analisis data, dan pembahasan di atas, maka dapat disimpulkan bahwa ada pengaruh model pembelajaran Cooperative Learning Tipe Group Investigation terhadap hasil belajar matematika pada aspek kognitif siswa kelas V SDN 26 Ampenan tahun ajaran 2019/2020. Hal ini dibuktikan dengan meningkatnya nilai pretest dan posttest pada kelas eksperimen yaitu dari nilai 47,92 meningkat menjadi 73,75. Hasil perhitungan t-test memperoleh nilai $t_{\text {hitung }} 6,561$ lebih besar dibandingkan nilai $t_{\text {tabel }} 1,675$ serta sintaks kegiatan pembelajaran siswa menggunakan model pembelajaranCooperative Learning tipe Group Investigation pada pertemuan pertama dan kedua terlaksana dengan sangat baik.

\section{DAFTAR PUSTAKA}

Alimuddin, H. (2017). Penerapan Model Pembelajaran Kooperatif Tipe Group Investigation Terhadap Hasil Belajar Matematika.Jurnal Pendidikan Matematika, 1(2), 13-15.

Annizar, A. M., Maulyda, M. A., Khairunnisa, G. F., \& Hijriani, L. (2020). Kemampuan Pemecahan Masalah Matematis Siswa dalam Menyelesaikan Soal PISA pada Topik Geometri. Jurnal Elemen, 6(1), 39-55. https://doi.org/10.29408/jel.v6i1.1688 Arikunto, S. (2014). Prosedur Penelitian Suatu Pendekatan Praktik. Jakarta: Rineka Cipta. 
Widyasari, dkk. (2020). Pengaruh Model Pembelajaran...

Ayuwanti, I. (2016). Meningkatkan Aktivitas Dan Hasil Belajar Matematika Menggunakan Model Pembelajaran Kooperatif Tipe Group Investigation Di SMK Tuma'ninah Yasin Metro. Jurnal SAP: Susunan Artikel Pendidikan,1(2), 8-9.

Dimyati. (2013). Belajar dan Pembelajaran. Jakarta: Rineka Cipta.

Indrawati. (2018). Pembelajaran Group Investigation Meningkatkan Hasil Belajar Matematika Siswa. Jurnal, Ekonomi dan Pendidikan, 1(1), 2-5.

Linuhung, N., \& Sudarman, S. W. (2016). Pengaruh Pembelajaran Kooperatif Tipe Group Investigation (GI) Terhadap Kemampuan Penalaran Matematis Siswa Mts. Aksioma: Jurnal Program Studi Pendidikan Matematika,5(1), 52-60. http://dx.doi.org/10.24127/ajpm.v5i1.465.

Maulyda, M. A., Hidayati, V. R., Rosyidah, A. N. K., \& Nurmawanti, I. (2019). Problemsolving ability of primary school teachers based on Polya's method in Mataram City. Pythagoras: Jurnal Pendidikan Matematika, 14(2), 139-149. https://doi.org/10.21831/pg.v14i2.28686

Maulyda, M. A., Sukoriyanto, S., Hidayati, V. R., Erfan, M., \& Umar, U. (2020). Student Representation in Solving Story Problems Using Polya Steps. Formatif: Jurnal Ilmiah Pendidikan MIPA, 10(1). https://doi.org/10.30998/formatif.v10i1.4629

Mayarani, Artini \& Fitriana. (2017). Perbandingan Hasil Belajar Matematika Siswa Antara Model Pembelajaran Kooperatif Tipe Group Investigation dan Student Teams Achievement Division. Jurnal Penelitian Pembelajaran Matematika Sekolah, 1(1), 5.

Nurlaeli., \& Yulianti, S. (2014). Penerapan Model Pembelajaran Kooperatif Tipe Group Investigation Berbasis Lesson Study Untuk Meningkatkan Hasil Belajar Kognitif Pada Materi Teorema Pythagoras Siswa Kelas VIII SMPN 1 Gunungsari. Jurnal Media Pendidikan Matematika, 2(1), 94-98.

Putri, D. D. H., Dewi, N. K., \& Rosyidah, A. N. K. (2020). Pengaruh Model Pembelajaran Kooperatif Tipe Team Quiz Terhadap Hasil Belajar Matematika Siswa Kelas IV SDN 20 Ampenan. Progres Pendidikan, 1(3), 225-235. https://doi.org/10.29303/prospek.v1i3.27

Rusman. (2012). Belajar dan Pembelajaran. Bandung: Alfabeta.

Sudjana, N. (2017). Penilaian Hasil Proses Belajar Mengajar. Bandung: PT Remaja Rosdakarya.

Sugiyono. (2017). Metode penelitian Kuantitatif Kualitatif dan $R \&$ D. Bandung: Alfabeta. 
Widyasari, dkk. (2020). Pengaruh Model Pembelajaran...

Purwanto. (2016). Evaluasi Hasil Belajar. Yogyakarta: Pustaka Pelajar.

Ulia, N. (2016). Peningkatan Pemahaman Konsep Matematika Materi Bangun Datar Dengan Pembelajaran Kooperatif Tipe Group Investigation Dengan Pendekatan Saintifik Di SD. Tunas Bangsa Journal, 3(2), 55-68. https://ejournal.bbg.ac.id/tunasbangsa/article/view/626 